\title{
AMAR
}

AMAR (Andalas Management Review)

Vol. 3, No. 2 (2019) 1-13

The Management Institute, Faculty of Economics, Andalas University

ISSN (Print) 2476-9282 | ISSN (Online) 2548-155X

\section{Analysis of Gender Differences in Determining Online Purchase Decision-Making Style on Fashion Products in Padang City}

\author{
Yulmi Suaria, Linda Watib, Surya Dharmac \\ Management Departement, Faculty of Economics, Bung Hatta University, \\ yulmisuari@gmail.com ; lindawati@bunghatta.ac.id ; sdharma@gmail.com
}

\begin{abstract}
Online shopping behavior refers to the process of purchasing products and services through the internet. Online Shopping is one of alternatives to purchase goods or services by men and women who are target market groups for marketers. Men and women tend to have different ways of thinking. The purpose of this study is to describe the differences between men and women, observed from their rationality in making decisions to purchase fashion products online. This study uses a decision-making style approach developed by Scott and Bruce (1995). In this study, the population is consumers living in the city of Padang who have purchased fashion products online at online shopping sites. There were 138 respondents who were sampled in this study. The sampling method uses accidental sampling. Data were analyzed using the Independent Sample T-test. This study found that there were differences in decision-making styles between men and women in purchasing fashion products online. In this case men are said to be more rational than women in making purchasing decisions online.
\end{abstract}

Keyword: Online Shopping, Buyer Decision Making Style

\section{INTRODUCTION}

Online shopping is an activity to purchase goods and services through internet media. This refers to consumer behavior in shopping at online shop or stores. Online shopping is one of the most popular activities on the internet and the number has increased every year.

The high number of online shops makes consumers have to be selective in determining the sites chosen to make purchases. There is high enthusiasm of consumers in conducting transactions online, therefore a survey was conducted by distributing questionnaires to 50 people in the city of Padang as respondents, of which the majority of respondents were women as much as $62 \%$ while the male respondents were $38 \%$. Most of the respondents are college students. All respondents stated that they have made purchases online in the past 6 months. From this, $76 \%$ of respondents stated that what they often buy is a type of fashion product. They think that fashion products can be a better-quality in online 
purchases than other offline products because the purchase risk is found to be smaller, more product choices, and the fashion trend is growing so fast.

Gender in the study of consumer behavior is one of the important factors in market segmentation. Although in this era of globalization, gender equality has always been upheld by society, men and women are considered to have the same ability to make decisions. Even though it is clear that they have different attitudes and behaviors, psychologically, men are said to be more likely to use logic and think rationally in solving problems whereas women are more likely to use their feelings or prioritize their emotional side when solving problems..

Some studies involving gender have shown that biological differences between men and women are also reflected in the their personalities, social relationship and roles. From the consumers point of view, it is stated that men and women go through different processees. The show different moods and have different preferences when both are in same condition. Meyers - Levy (1991) explains that women can evaluate situations, events and messages that they target in detail. While men only focus on goal and remain indefferent to what is outside of their goals. According to Unal and Ercis (2008) women are more active in trying new brands and store they know. Men Also more concerned with the factor of being aware of high quality and easy to reach factor in buying a product.

Taking into account the diversity of behaviors between male and female consumers, it is not possible for all behaviors to be identified as a whole, in order to find out their needs and desires. Therefore marketing research is needed regarding the decision-making styles of men and women in taking action to purchase fashion products online. Based on the background of the problem, the purpose of this study is to analyze the differences between men and women, which are seen from their rationality when making decisions to purchase fashion products online. Therefore, the difference in decision making styles of online fashion purchases between men and women in Padang city needs to be empirically proven.

\section{LITERATURE REVIEW}

Schiffman and Kanuk (2007: 6) suggest that the study of consumer behavior is centered on the way individuals make decisions to utilize their available resources (time, money, effort) to buy goods related to consumption. This includes what they buy, why they buy, when they buy, where to buy it, how often it is bought, and how often they use it. 


\subsection{Buying decision}

Consumers are individuals who identify their needs and desires and determine what products or products they use during the consuming process. Purchasing decisions are defined as an integration process that combines knowledge to evaluate two or more alternative behaviors, and chooses one of them (Setiadi, 2010: 342). The result of this integration process is a choice, which is presented cognitively as a desire to behave.

\subsection{Types of Purchasing Behavior}

Purchasing behavior for each product varies. Consumer purchases can be reviewed as an activity to solve a problem. More complex decisions usually involve the participants of the purchase and consideration of more buyers. Kotler and Armstrong (2008: 177) explain that there are four types of consumer buying behavior. The levels of buyer involvement and level of brand differences include complex purchasing behavior, dissonance purchasing behavior, habitual purchasing behavior, seeking diversity purchasing behavior. A consumer is said to undergo complex buying behavior if consumers involvement in purchasing are high and they have a meaningful view between brand differences.

Habit consumer behavior is a consumer who makes habits in buying characterized by consumer involvement in low purchases and they have a meaningful view between brand differences whereas consumer behavior in buying that seeks diversity is characterized by situations where their involvement is low, but considers meaningful differences between brands.

\subsection{Typology of Consumer Decision Making}

Sproles and Kendall (1986) developed the methodology of consumer decisionmaking style or known as CSI (Consumer Styles Inventory) by identifying the basic characteristics in consumer decision making about consumer interest when deciding to buy. Their research identified eight consumer purchasing decision-making styles, namely perfectionist awareness, brand awareness, awareness of the latest models or styles, hedonic awareness, price awareness, awareness of impulsive shopping, confusion of over choices, and habitual awareness.

With the advent of current e-commerce businesses, the CSI model developed by Sproles and Kendall (1986) was modified to fit the e-commerce environment. The O-CSI (Online Consumer Styles Inventory) model was later developed by Yang and Wu (2007) and 
scores of online consumer decision making factors can be calculated and analyzed in order to accurately predict online consumer behavior.

They identified six characteristics of online decision making styles, namely perfectionist awareness, brand awareness, fashion awareness, confusion on over choices, brand loyalty (consumer habits), and impulsivity. Two characteristics are omitted, namely awareness of price and hedonism. Prices in online shopping tend to be programmed as problem solvers when making purchasing decisions and shopping online is not considered a recreational or hedonic activity.

Scott and Bruce (1995) develop measurement tools for measuring consumer decision making processes that are consistent both conceptually and psychometrically. The tool they developed is somewhat different from previous studies. In contrast to empirical studies and theories that existed before, the study focused more on aspects of the decision-making task and the situations that might influence it. However, the less attention relativity in previous studies has been clarified by the characteristics of the decision-making styles they have developed.

Scott and Bruce (1995) define decision-making styles as traits or patterns of habitual responses that are learned and demonstrated by an individual when faced with a situation of purchasing decisions in which these traits are not personality but tendencies based on habitual reactions to certain decisions. The four decision-making styles identified from this study are rational decision-making style, intuitive decision-making style, dependent decision-making style, avoidant decision-making style (avoidant), and an additional, spontaneous decisionmaking style.

\subsection{Gender Differences in Consumer Behavior}

Many opinions agree on the notion that women are more emotional than men, and that men are more rational than women. Basically men and women have distinctive qualities that are superior to each other. Generally, women have the ability to empathize better than men, while men are superior in systems of thinking and analyzing. When women face a problem they are more likely to stick with the feelings they experience while men immediately cannot stand the situation so they decide quickly to find a solution to solve it. Klein and Hudgos (2001) explain that women have a greater degree of empathy than men. This difference is caused more by motivation. Women have greater motivation to understand what other people think and feel. 
Fatimah (2012), explain that ethnic Minangkabau is one of the largest ethnic in Indonesia, which has a matrilineal kinship system. In the matrilineal ethnic Minangkabau kinship system, women get a different position when compared with women in patrilineal sociaties. When carefully scrutinized, matrilineal culture actually contains the value of equaty and justice, both in the order of philosophy, structure and implementation should be.

The assumption that which gender uses logic and feelings between men and women is indeed entirely based on the view and understanding of society. Barret and Bliss-moreau (2009) explain that society generally perceives when a woman expresses her emotions, it is considered as the nature of an emotional being. Tufail and Poletta (2015) describe men showing their emotional behavior because he is in a bad condition or situation that forces him to show his emotions.

Liu and Mihalcea (2007) explain that in terms of sensibility to information, men and women basically respond equally to different rational and emotional. Women tend to focus on time immediately or at the same time, shades of color, proximity or lack of a relationship, explanation of the size of objects, and showing happiness and sadness. While in men, their main focus are mainly on long periods of time, basic colors, having relationships, abstract thoughts, focusing on anger and what is the cause.

Sudjarnati, et all ( 2018) explain this study aims to determine the effect of shopping orientation on online information search and online shopping, as well as differences in men and women in shopping orientation. Thetype of research used in this study is quantitative research with descriptive causal types. The study population was students of the 2017/2018 Academic Year of Malang State Polytechnic who had made an online purchase.

In the study of consumer behavior, gender is an important factor, taken into account in market segmentatio, product positioning and promotion. To develop a successful strategy, it is necessary to determine how men and women respond to marketer's practise, why they prefer their products, brands and behavior in the marketplace. Some studies involving gender show men and women want different products and have different tendencies in thinking.

According to Unal and Ercis (2008) there are several differences in males and female characteristics in shopping decisions. The Characteristic of women in shopping are that they are more aware of the latest fashion. They are more interested in buying up to date things and something interesting. Women tend to look for different brands in different stores. Buying quality products is very important for them and spending more time searching for these products. 


\subsection{Review on Previous Research Review}

Previous research was conducted by Yang and Wu (2007) who examined gender and consumer decision making online. This research categorizes online buyers into six main decision-making styles, namely perfectionism, brand awareness, awareness of the latest fashions, impulsive shopping, confusion over choicees, consumer habits. In this study there are differences in decision making between genders in online shopping. The differences lie in brand awareness and the latest fashions. Female consumer decision making is dominated by new style while male decision making is dominated by brands.

Another research was conducted by Bakewell and Mitchell (2006) who examined male versus female consumer decision making styles. In this study, they used eight CSI styles and added four new female factors. Gender differences are still seen in men who are still brand conscious than women. Brand awareness can be seen as a reflection of men's desire to use shopping as a demonstration of their superiority, namely shopping to win.

Research conducted by Unal and Ercis (2008) examined the role of gender differences in determining consumer decision-making styles found that men and women living in Erzunum, Turkey, have different decision-making styles, namely awareness of well-known and open to brands or new things and important changes to meet the tastes of female respondents. Women are more active in trying various brands and changing brands that they use more often.

The research conducted by Shabbir and Safwan (2014) examined the approach of consumer characteristics in shopping and gender differences in Pakistan. The results of the study found that there were differences in decision-making styles between men and women. Women in Pakistan are generally more aware of brands, the latest fashion, and hedonists and more impulsive than men. Men in Pakistan are aware of brands, like to buy branded clothes and more considering this aspect when shopping.

Research conducted by Mitchell and Walsh (2004) examined gender differences in consumer decision-making styles in Germany. In this study, it was found that the decisionmaking styles of male and female consumers varied. However it seems that four factors of brand awareness, perfectionism, confusion of over choices, and impulsivity are common in gender differences.

Based on existing studies on CSI (Consumer Styles Inventory), decision making style can be re-evaluated and adjusted. The scale can be redesigned and developed and tested for comparison. Perspectives that emerge from the results of modeling may be used as a way to 
develop the equality of research results. CSI will be a tool to offer practitioners to improve cross-nation segmentation and targeting.

A number of researchers who study the style of decision making focus on the way in which individuals collect and process information. Individuals carry habits and strategic modes of thinking to bear the task of managing information in their environment and processing information. In the stage of gathering information in decision making, individuals depend on pre-defined concepts and cognitive categorization to filter data. In the information processing phase, good decision making and problem structure in terms of methods tend to lead to solutions or use repeated or trial-and-error solutions testing strategies.

\section{RESEARCH METHOD}

The determination of the number of samples in this study uses the Chochran formula (1963: 75) in Sarwono (2014: 196). Based on these calculations, a minimum of 138 respondents will be sampled in this study.

\subsection{Sampling technique}

The sampling method used in this study is the accidental sampling method. Sugiyono (2010: 67) states that the accidental sampling method is a technique for determining samples based on chance, that is, anyone who accidentally meets a researcher can be used as a sample, if it is viewed by the person who happened to be found is suitable as a data source.

\subsection{Definition of Operational Variable .}

Peter and Olson (2013: 162) define consumer decision making as an integration process in buying a product by combining knowledge to evaluate two or more alternatives and choose one of the alternatives.

For the variables of Consumer decision-making style in this study are adapted questioner from Scott and Bruce (1995) by using the following indicators: rational decisionmaking style, intuitive decision-making style, dependent decision-making style, avoidant decision-making style, and style spontaneous decision making.

\subsection{Data Analysis Method}

\section{Independent Sample T-test Testing}

Testing of two samples that were not related using the Independent Sample T-Test. Sugiyono (2010: 162) states that this test was used to determine whether or not there were 
differences between the two groups of unrelated samples. In this study, using the Independent Sample $\mathrm{T}$ - test is to find out whether there are differences in decision making styles between men and women

The formula for the Independent Sample T-test is as follows:

$$
t=\frac{\overline{x_{1}}-\overline{x_{2}}}{\sqrt{\frac{\left(n_{2}-1\right) s_{1}^{2}+\left(n_{2}-1\right) s_{2}^{2}}{n_{1}+n_{2}-2}\left(\frac{1}{n_{1}}+\frac{1}{n_{2}}\right)}}
$$

Where :

$\left(\mathrm{x} \_1\right)^{-}=$Sample average 1

$\left(\mathrm{x} \_2\right)^{-}=$Average sample 2

n_1 = Number of samples 1

$\mathrm{n} \_2=$ Number of samples 2

S_1 = Standard deviation of sample 1

s_2 = Standard deviation of sample 2

Decision criteria using a confidence level of $90 \%$ or a significant level of $10 \%(0.1)$, then for testing the independent sample t-test is if the significant value is $<0.1$, then the decision is that there are differences between the two groups. If the significant value is $>0.1$, the decision is that there is no difference between the two groups.

\section{RESULTS AND DISCUSSION}

\subsection{Descriptive Respondents by Gender and Age}

In accordance with the tabulation process data that has been carried out, demographics of respondents based on gender and age of the respondents can be grouped as follows:

Table 1. Descriptive Respondent by Gender and Age

\begin{tabular}{cccccc} 
Gender & N & Minimum & Maximum & Mean & Std. Deviation \\
\hline Men & 54 & 19 & 45 & 23 & 4,39 \\
\hline Women & 84 & 18 & 37 & 22 & 3,80 \\
\hline Total & 138 & 18 & 45 & 22 & 4,04 \\
\hline
\end{tabular}

Source : SPSS Data

Based on the gender of respondents who answered this questionnaire, there are more women, as many as 84 people, compared to men, 54 people. The average male respondent is 23 years old. The lowest age for male respondents is 19 years and the highest age is 45 years. On average, the age of female respondents were 22 years old. The lowest age of female 
respondents was 18 years while the highest age was 37 years. Of the total respondents, their average age is 22 years.

\subsection{Descriptive Respondents Based on Education}

The Demographics of respondents is based on the education. Based on the results of the study, most of the respondents' last education is high school students with men as many as 39 people and women 63 people. Respondents with diploma education, men 3 people and women 5 people, then those with a Bachelor degree (S1), men 12 people and women 15 people and 1 Postgraduate (S2) male respondent.

\subsection{Descriptive Respondents Based on Website Accounts}

Below is demographic of respondent based on the sites in which the respondent has an account:

Table 2. Descriptive Respondents Based on Accounts

\begin{tabular}{lccc}
\multirow{2}{*}{ Websites } & \multicolumn{2}{c}{ Jenis Kelamin } & \multirow{2}{*}{ Jumlah } \\
\cline { 2 - 3 } & Pria & Wanita & \\
\hline Lazada & 17 & 25 & 42 \\
\hline Zalora & 4 & 6 & 10 \\
\hline Shopee & 7 & 22 & 29 \\
\hline Tokopedia & 1 & 2 & 3 \\
\hline Bukalapak & 2 & 1 & 3 \\
\hline Blibli & - & - & - \\
\hline Lainnya & - & - & - \\
\hline Memiliki lebih dari satu akun & 23 & 28 & 51 \\
\hline Source : SPSS Data & & &
\end{tabular}

From table 1.3, it can be seen various online site accounts owned by male and female respondents in making purchases online. Most men have an account on the Lazada site, 17 people whereas female respondents with an account on the Lazada site are 25 people. However, from male and female respondents, they also have several accounts on other sites or have more than one online site. For men, 23 people have accounts of more than one online site and for women there are 28 people having accounts of more than one site. 


\section{The Result from Independent Sample T-test T}

Table 3. Independent Sample T Test Testing

\begin{tabular}{ccccc}
\hline Variable & T & Sig & A & Conclusion \\
\hline $\begin{array}{c}\text { Rational Decision } \\
\text { Making Style }\end{array}$ & 1,980 & 0,05 & 0,1 & There is difference
\end{tabular}

Source : SPSS Data

The results of the Independent Sample T-test showed that the significant value produced was 0.05 . This means that the resulting sig value is smaller than the alpha value of 0.1. It can be concluded that there are differences in rational purchasing decision-making styles between men and women. The calculated $t$ value obtained from the test results is positive. This means that the average of the first group average is higher than that of the second group The average male rational decision-making style is 15,203 while the average women rational decision-making style women is 14,476 .

From the average value, it can be seen that the average value of men is higher than that of woman. It can be concluded that men are more rational than women in making online purchasing decisions.

\subsection{Discussion}

Analysis of decision-making style was developed by Scott and Bruce (1995) explaining that there are four decision-making styles, namely rational, intuitive, dependent, and avoidant as well as an additional style, which is spontaneous decision-making style. The five styles are measured using twenty-four statement items. This study discusses the difference in rationality between men and women in making purchasing decisions online aiming to see which gender are more rational in making purchasing decisions online. This study uses only one style approach, namely rational decision-making style and only uses four item statements.

From the results of testing done using the Independent Sample T-test, it can be concluded that there are differences between men and women in terms of their rationality when making purchases online in which men are said to be more rational than women in online purchases. The results of this study were not discussed in previous studies, because in previous studies, it only discussed about decision-making styles between men and women with eight approaches characteristic of consumer interest developed by Sproles and Kendall (1989). 
However, in research using the characteristic interest approach of consumers, it is also found that there were differences between gender in consumer decision making. Research conducted by Yang and Wu (2007) discusses gender and online decision-making styles, found that there are differences in decision-making styles between men and women in shopping online. The difference seen in men is dominated by brands while women are dominated by new models. Research conducted by Bakewell and Mitchell (2006) which examined male versus female consumer decision making styles found that there were differences between men and women in consumer purchasing decisions. Gender differences are seen as brand-conscious characteristics where in this study men are more aware of brands than women.

Research by Sudjanarti et all (2018) which determine the effect of shopping orientation on online information search and online shopping, as well as differences in men and women in shopping orientation. The results of the research found that there is no difference in shopping orientation between men and women

The study conducted by Fatimah (2012) which the matrilineal kinship system turns out to position women and men equally. Man placed as protectors and supervisors, presented with honorable position (prestige) as "mamak ", whereas women have access to property. While in decision making should be both men and women have the same access.

In a study conducted by Unal and Ercis (2008) which examined the role of gender differences in determining consumer decision-making styles, it was found the difference between men and women is in impulsive characteristics. This means that men often regret purchases they don't plan while women often make purchases that are not on their shopping list. Another research was conducted by Shabbir and Safwan (2014) who examined the approach of consumer characteristics in shopping and gender differences in Pakistan. The results of the study found that there were differences in decision-making styles between men and women. Men are brand conscious while women are more aware of new, more impulsive fashion style.

\section{CONCLUSION AND IMPLICATIONS}

Based on the research that has been done, it can be concluded that there are differences in decision-making styles between men and women in purchasing fashion products online. In this case, men are said to be more rational than women when making purchases online. 


\subsection{Research Implications}

Based on the results of the research, online shop sites pay attention to the demographic segmentation of prospective customers, especially on gender segmentation, type of work, estimated expenditure, frequency of consumers in shopping online, frequently purchased products, online consumer accounts, and frequently used sites. This gives a significant difference in the determination of online purchasing decisions.

The onlineshop should still determine target consumers, because of them differences in buyer decision-making styles between men and women. Onlineshop must adjust with the needs of consumers to attract more store visitors and also increase the number of sales.

\subsection{Research Limitations}

The research that has been done is still not perfect and has limitations including:

1. This study only analyzes and describes gender differences between men and women in terms of their rationality when making purchases online while there are still many other aspects that can be used to analyze differences.

2. This study only limits one characteristic of decision-making styles, namely rational decision-making styles while the characteristics of other decision-making styles such as intuitive decision-making styles, dependent decision-making styles, avoidant decision-making styles (avoidant), and spontaneous taking styles are not analyzed in the scope of this research.

\section{REFERENCES}

Bakewell, Cathy and Mitchell, Vincent (2006), "Male Versus Female Consumer Decison Making Style", Journal of Business Research, Vol. 59, No. 1, pp.1297-1300.

Baret, Lisa F dan Bliss Moreau, E (2009), "She's Emotional. He's Having a Bad Day", Attributional Explanation for Emotion Stereotypes, Vol. 9, No. 5, pp.649-658.

Dwi Sudjanarti, Umi Khabibah, Tri Istining Wardani (2018), "Pengaruh Orientasi Belanja dan Perbedaan Gender Terhadap Informasi Online dan Belanja Online Pada Mahasisiwa Jurusan Administrasi Niaga Politeknik Negeri Semarang", Jurnal Administrasi dan Bisnis, Vol. 12, No. 2.

Fatimah, Siti (2012), “Gender Dalam Komunitas Masyarakat Minangkabau : Teori, Praktek dan Ruang Lingkup", Jurnal ilmiah Kajian Gender, DOI : 10.15548/jk.v2i1.37

Klein, Kristi J dan Hodges, Sara D. (2001), "Gender Difference, Motivation, and Empathic Accuracy : When It Pays to Understand" Personality and Social Psychology Bulletin, Vol. 27, No. 6, pp.720-730.

Kotler, Philip dan Amstrong, Gary (2008), Prinsip-Prinsip Pemasaran : Edisi 12 Jilid 1, Erlangga, Jakarta. 
Liu, Hugo and Mihalce, Rada (2007), “Of Men, Women, and Computers”, Data Driven Gender Modeling for Improved User Interface, ICWSM, pp.73 -74.

Meyers Levy, J. (1991), “Exploring Differences in Male's and Female's Processing Strategies", Journal Of Marketing Research, Vol.10, No.1-63.

Mitchell, Vincent W dan Walsh, G. (2004), "Gender Difference in German Consumer Decisions-Making Styles", Journal of Consumer Behavior, Vol. 3, No. 4, pp.331-346.

Peter, J Paul dan Jerry, C Oslo (2013), Consumer Behavior : Prilaku Konsumen dan Strategi Pemasaran, Edisi 9, Salemba Empat, Jakarta.

Sarwono, Jonathan (2014), Analisis Data Penelitian Menggunakan SPSS 22, Andi Publisher, Jakarta.

Schiffman, Leon dan Kanuk, Leslie Lazar (2007), Perilaku Konsumen, Edisi Ketujuh, Indeks, Jakarta.

Scoot, Sussane G and Bruce, Reginald A. (1995), “Decision Making Style : The Development and Assessment of A New Measure", Educational and Psychologi Measurement, Vol. 55, No.55, pp.818-831.

Setiadi, Nugroho (2010), Perilaku Konsumen, Kencana Prenada Grup, Jakarta.

Shabbir, Javeria dan Safwan, Nadeem (2014), "Consumer Shopping Characteristic Approach and Gender Difference in Pakistan", Journal of Marketing Management, Vol.2, No.2, pp.1-28.

Sproles, George B and Kendall, Elizabeth L. (1986), “A Methodologi for Profiling Consumer's Decision Making Styles", The Jurnal of Consumers Affairs, Vol.20, No.2, pp.267-279.

Sugiyono (2010), Metode Penelitian Bisnis, Alphabeta, Bandung.

Tufail, Z., \& Polletta, Z. (2015), "The Gendering of Emotional Flexibility: Why Angry Women Are Both Admired and Devalued in Debt Settlement Firms", Gender \& Society, Vol. 29, No. 4, pp.484-508.

Unal, Sevtap dan Ercis, Aysel (2008), "The Role Of Gender Differences in Determining The Style of Consumer Decision-Making", Bogazici Journal, Vol.22, No.1-2, pp.89-106.

Yang, Chyan dan Wu, Chia C. (2007), "Gender And Internet Consumer's Decision-Making", Cyber Psychology \& Behavior, Vol. 10, No. 1, pp.86-91. 